\title{
Grand Hotel: Portrayal of Women in Golden Age Hollywood
}

\author{
Dan Li
}

\begin{abstract}
-1930s is defined by many scholars as the golden age of Hollywood. Women's roles were changing along with the social transformations. Film became a powerful tool to portray women's images. This paper analyzes women's images on screen in 1930s using Grand Hotel (1932) as an example, as well as some other representative films, aiming to explain how and why women were portrayed in certain ways on screen in golden age Hollywood. It interweaves key principles and methodologies including feminist theory, gender studies, spectatorship, and film history. It is found that the most influential factors are female filmmakers' status in the industry, psychological needs of the spectators, and the controls on motion pictures.
\end{abstract}

Index Terms-Feminist theory, film studies, gender and communication, women studies.

\section{INTRODUCTION}

"[Flaemmchen's character] best exemplified the changing role of women in the Thirties society and film." - Nina Nichols, "Program Notes," 1980 [1]

1930s is defined by many scholars as the golden age of Hollywood. Film industry in this period has witnessed the Great Depression, the coming of sound, and multiple emerging controls from various parties. Women's roles were changing along with the social transformations. Film became a powerful tool to portray women's images in that certain period of time. This paper analyzes women's images on screen in 1930s using Grand Hotel (1932) as an example, as well as some other representative films.

In 1932, Metro-Goldwyn-Mayer (MGM) presented Grand Hotel, which was a major hit and won the Academy Award for Best Picture. The film was adapted from the German novel Menschen im Hotel by Vicki Baum. The novel was published in 1929 and later became "one of the most successful popular culture products ever created by a German-language writer [2]." When it was translated into an English version, it quickly became an international best-seller [3]. There are two major female characters in the film - the ballerina Grusinskaya, and the stenographer Flaemmchen. These two characters represent women in 1930s, which are taken as examples when analyzing the portrayal of women in motion pictures. Interweaving feminist theory, gender studies, spectatorship, and film history, this essay applies key principles and methodologies to topics including the change of female filmmakers' status in the industry since the silent era, psychological needs of the spectators, and the controls on motion pictures.

Manuscript received July 2, 2013; revised September 5, 2013.

Dan Li is with the University of Texas at Austin, Austin, TX 78712 USA (e-mail: danli@utexas.edu).

\section{HISTORY AND PRINCIPLES}

\section{A. Power of Women Faded Away with the Coming of Sound}

From the silent era to sound era, women in film industry experienced significant changes.

In the silent era, the primary stage for women to actively show strength was writing. Women worked as scenarists. However, they did not exploit this power to advocate an aggressive feminist standpoint. As a number of film critics and historians have pointed out that, there was no overt "feminist" political agenda among women filmmakers in silent era, despite the fact that the first-wave feminism was already under way by World War I [4]. In Thomas Slater's study of director/writer Lois Weber, he pointed out that though women filmmakers may have operated within Victorian conventions, they were quite progressive in how they handled those conventions [5]. In most films written by women, the cult of true womanhood was identifiable and evident. Especially in "melodramas," they emphasized on women's virtues of piety, purity, domesticity and submissiveness [6]. These stories served as a form of escaping, which temporarily allow female audience to get out of the home or out of the workplace. The female characters on screen were pro-active while within bounds, and they enticed men rather than challenged them [7].

Besides scene writing, women also had a greater share of directing assignments. According to historian Anthony Slide, "During the silent era, women can be said to have dominated the industry. There were over thirty women directors prior to 1920 , more than at any other period of film history . . . the women directors were considered equal to, if not better than, their male colleagues [8]." A number of women, like Alice Guy and Lois Weber, were versatile in writing, directing and producing to ensure their authorship in creativity. These women were powerful in Hollywood because they held multiple positions in the industry. Some even had their own production companies [9].

However, there was a sharp turn of this situation when Hollywood entered into sound era. First, nearly all the women who wrote in Hollywood disappeared. Two reasons are detected to explain this tipping point. First, women are believed to have been much better novelists than dramatists. In the silent era, the female scenarists' job was very similar to writing novels. But writing a screenplay is not their strength, if not a weakness. According to McGilligan, "A silent film was like writing a novel, and a script was like writing a play. That's why women dropped out. Women had been good novelists, but in talking pictures women were not predominant. You can't tell me the name of one good woman 
dramatist [10]." The other possible reason is that male workers in the industry were not willing to partner with women in filmmaking. Some of the writer/directors, like Alice Guy, were literally pushed out of the male dominated production side when men simply did not want to work with women in this capacity [11].

Meanwhile, women lost jobs as directors in 1930s as is shown in the 2000 documentary, Reel Models: The First Women of Film. A 1920 book entitled Careers for Women categorized film direction as a possible career choice for women, but when it was reprinted in 1933, the chapter was omitted [12]. By 1927, Dorothy Arzner was the only woman in the U.S. directing studio films [13]. From the 1930s to the arrival of director Ida Lupino in the 1950s, Arzner was the only one female director in Hollywood. Wanda Tuchock had a one off in 1933, and there were no further outcomes from her again.

Two theories are used to explain why women continued to be under-employed as film directors: human capital theory and discrimination theory. Human capital theory holds the belief that women did not put as much efforts in filmmaking as men because they invested more time in child bearing and rearing. Besides, they had less chance to get education from film schools and even attending film festivals. Thus they were less successful in this industry. Gradually, women self-select out of film directing [14]. In contrast, discrimination theory suggests that the employers, producers and studio executives, prefer to hire men instead of women as directors based on their gender discrimination. In addition, occupational discrimination from the society discouraged women to pursue a career in film directing [15]. As a result, "women were no longer able to rise quickly to positions of authority, nor indeed to move so easily from one function to another-actress to writer to director. On-screen they maintained, even increased, their status; off-screen their influence faded [16]."

Under the phenomenon of fading female power in the industry, Vicki Baum, the writer of Menschen im Hotel, exercised hardly any control on the filmmaking process of Grand Hotel, even on the adaptation of the novel. Among the reviews on newspapers about her transformation of the novel into fifteen episodic pictures, Eloesser's review pointed out that the problems center around Baum's inability to translate characterization or plot elements from the novel to the dramatic form [17]. During Baum's 1931 U.S. trip, she traveled to Hollywood to write an adaption of the novel for MGM, but her ideas did not please Irving Thalberg, and she became a "voluntary technical advisor," according to the film's press book and Baum's memoirs, Es war alles ganz anders [18]. Finally, the screenplay for the film was written by Hans Kraly based on William A. Drake's stage adaptation, became the classic Grand Hotel [19]. Therefore, creation of the characters of Grusinskaya and Flaemmchen were fundamentally based on two men's opinions. Their views on women influenced the character development significantly. Following the fading power of women in golden age Hollywood, "male gaze" took its control on female images on screen.

\section{B. The Psychological Needs of the Spectator}

As Victorianism continued to influence female images in films, stories were subject to male domination and control since people believed true women were passive creatures dependent upon men for protection and support. Screen heroines became even more subservient to male imperatives in the twenties [20]. Under male domination, two basic Freudian concepts, voyeurism and fetishism, explain what woman represents and what male spectators were thinking about when watching a female screen image.

The first concept voyeurism is elaborated through male fantasies. For men, the "I" of identity remains central, and it is never in the female narration. Many male fantasies focus on the man's excitement in arranging for his woman to expose herself, or even give herself to other men, while he watches [21]. This male voyeurism and the female form are shockingly different. When woman watches, it fails to arouse any desire in her. Instead, she tries to keep herself away from sex. Man, on the contrary, owns the desire and the woman. He gets pleasure from exchanging the woman, as indicated in Levi-Strauss's kinship system [22].

In Grand Hotel, both Grusinskaya and Flaemmchen served this psychological need of men. When Grus locked herself in the apartment, the Baron was hiding in the closet. He watched in darkness. From the Baron's angle of view, the audiences noticed that the shadow in the room was moving as Grus changes her dance costume into pajamas. The audience does not know if the Baron was able to see Grus naked. But it is this question in mind that triggers men's fantasy on dreaming about seeing what they desire. For Flaemmchen, the hint is even more explicit. Her sexual appeal was designed on purpose as the audiences see her in the deep-v dress. She showed Preysing a nude picture she took for a fashion magazine. The picture is not shown to the audiences, which again encourages the viewer to imagine. When Flaemmchen agreed to stay the night in the hotel with Preysing, it is a form of giving herself to the male spectators through the story on screen.

Meanwhile, the character of Grusinskaya also reflects the second concept fetishism. The occupation of a ballerina star draws an elegant picture as the background for the character. In the beginning scene of the telephone booth, Grusinskaya is the only one who lived in the hotel but did not show up. Her nanny's conversation made the character even more mysterious and desirable. Grusinskaya always dressed in sexy pajamas, together with Garbo's theatrical movements, the character was successfully built as a physically beautiful and mentally graceful lady.

In other words, voyeurism and fetishism were used by filmmakers to attract male spectators in accordance with their unconscious needs. As Mulvey points out, fetishism "builds up the physical beauty of the object, turning it into something satisfying in itself," while voyeurism, linked to disparagement, has a sadistic implication. Usually it is involved with pleasure through control or domination and even with punishing the woman [23].

In addition, female spectators need to be taken into account. According to various trade papers, females comprised between $60 \%$ and $80 \%$ of the domestic cinema audience in 1930s [24]. Wives and mothers were representing their families at that period, which became one of the most important factors affecting the selection of styles and stories 
for films [25]. However, in Laura Mulvey's influential essay "Visual Pleasure and Narrative Cinema," she theorized that Hollywood cinema has been organized around masculine pleasure and desire through its narrative and optical structures [26]. "Regardless of the actual sex (or possible deviance) of any real live moviegoer," according to Mulvey, Hollywood cinema involves a "masculinization" of the spectator position [27]. In this sense, filmmakers might not primarily address the pleasure and desire of female spectators although they compromised a larger portion of audience. But Rodowick brought up an opinion to negate Mulvey's theory. He thinks that there is possibility that men may be erotic objects for women, or may be submitted to an economy of masochism [28]. Thus, both objects and subjects may be changeable in terms of sexuality. Under this notion, Grand Hotel is not a film that simply ignores the psychological needs of female spectators. Instead, it uses its male characters such as the Baron, and the romantic love stories to please female spectators.

\section{Controls on Motion Pictures}

One might argue that if the concept of voyeurism is the key, Grusinskaya and Flaemmchen appeared to be too conservative to please the spectators. They did not expose too much of their bodies, neither were they involved in any implied sex scenes. In the original novel, Grusinskaya had sex with the Baron but in the film the bedroom scene was downplayed. It was not until the next morning that we see them. The decision was made by the studio as they were controlled by social forces. American film in 1930s became the most controlled entertainment in the country [29].

Films in late twenties and early thirties were accused of having negative influence on both children and adults. As the accusation became increasingly fierce, during the thirties, different sources came into control of motion pictures. The first source was state and municipal censorship boards. The second source was pressure groups. These groups posed threat to films before releases. For example, women's organizations and religious groups had delegates to preview films and they had the right to condemn the films if they thought the content was inappropriate. The third control came from self-regulation, which was administered by the Production Code Administration (PCA), an arm of the Motion Picture Producers and Distributors of America (MPPDA).

In order to show respects to women, special aspects of the new Production Code, adopted in March 1930, were highlighted by Will Hays in an article published in Ladies' Home Journal in 1930. Hays indicates "The work of reflecting social and community values in the production of motion-picture entertainment has constantly progressed," in which aspects including treatment of marriage, scenes of passion and adultery, and use of liquor were addressed as evidence of the industry's "high sense of public responsibility" in developing movie content [30].

Under official control and social surveillance, Flaemmchen on the screen was much more innocent than the character in the German versions. In the bedroom scene, although Flaemmchen agrees to have sex with Preysing, viewers see her fully dressed while Preysing asks if she will "be nice to him" but before anything of a sexual nature happens between them, Preysing hears noises in the other room and leaves. No touching, no kissing, no undressing, no sex. Later Crawford does appear in a robe, which slips somewhat provocatively off her shoulder, but that is the most extreme moment of exposure of the whole film.

\section{ANALYSIS}

Based on the theories above, the two major female characters in Grand Hotel - Grusinskaya and Flaemmchen are highly representative of golden age Hollywood. In the film, Grusinskaya (Greta Garbo) comes to stay at the Grand Hotel in Berlin. As a famous ballerina, she performs at a theatre in the city. Baron von Gaigern (John Barrymore), an impoverished noble and adventurer, has come to the hotel to steal her jewels in order to pay his debts. After a performance, Grus returns to her apartment, disappointed by her fading career. The Baron is in her room hiding in the closet. Seeing that she is going to commit suicide, he reveals himself and claims he slipped into her room because he is an admirer. Eventually, they fall in love. Also at the hotel is Kringelein, a bookkeeper, who has an incurable disease and plans to enjoy his last months in Grand Hotel. He becomes friends with Flaemmchen (Joan Crawford), a stenographer, but she desires wealth, which ultimately brings her the feeling of safety. Preysing (Wallace Beery), an industrialist, has come to the hotel to negotiate a business deal which backfires. He is attracted to Flaemmchen and she, in need of money, agrees to have an affair with him. The Baron promises Grusinskaya that he will depart from the hotel and go with her to start a life together. Needing money, he attempts to rob Preysing's apartment. Preysing catches and kills the Baron. Kringelein keeps Flaemmchen out of the way when Preysing is arrested. Flaemmchen agrees to go away with Kringelein to spend the rest of his days traveling with him. Grusinskaya departs with her staff from the hotel, happily planning her new life with the Baron, unaware that he is dead.

Grusinskaya is a glamorized character. There were not many occupations suitable for women in 1920s. Being a ballerina was lucky compared to those unemployed girls. She was able to make a living by herself because she had unique talent in dancing. From this point of view, the Grus character does not reflect a typical girl in real world at that time. At first, she was worried about her performance that night. She lost her confidence because audiences were no longer showing interest in her performance. She was not as popular as before. Now we could tell that she is a fragile woman who cares too much about other people's opinions on her. The other possible reason for her depression, which has not been stated explicitly, is that she felt she was aging. She failed a performance and got back to her apartment. Following the famous quote: "I want to be alone," Grus locked herself in the room, with the Baron hidden in the closet. She was so desperate and wanted to commit suicide. There came the baron, with the lie of being an admirer of hers. Surprisingly, Grus believed him. On one hand, Grus's trust in the Baron indicates her innocence, which is a womanhood merit. On the other hand, one could perceive this plot as an underestimation of women's intelligence. To put it in another 
way, it is pure ignorance, which might be due to Grus's long-time absence from real social interaction. Finally the two fell in love. The irony is that, although she said that "I want to be alone," she simply accepted a stranger into her life within a short period of time. The only thing that changed Grus's mind is the love from a man she has been with only one night. The next day, after she came back from a successful performance, Grus could not wait to call the Baron and kept waiting for him in her apartment. To her, the future was for both of them together. But meanwhile, the Baron had plans for himself, without letting Grus know. Grus submits herself completely to the Baron, which indicates unbalanced statuses of these two characters.

The character of Flaemmchen, on the other hand, is more realistic. Flaemmchen first appeared in the Grand Hotel as a personal typist hired by Preysing. She immediately fits both the physical image and personality profile of the New Woman/Angestellte: young and slim with an athletic figure, she wears makeup, perfume, and a stylish felt hat over her curly bobbed hair [31].

Flaemmchen is a typical white-collar worker who earned just enough to survive in a dead-end job. She desired a film career and sought her start in the business by posing as a nude model for a Berlin magazine. She neither believes in true love nor expects a man to save her. Through her work as a stenographer in Berlin's Grand Hotel, she met General Director Preysing, a provincial industrialist. Flaemmchen knew clearly that she had sexual allure to men. Therefore she took a smart strategy. It proved successful when Preysing and the bookkeeper Kringelein were both attracted to her. Finally she got the chance to travel with a wealthy man. On the whole Flaemmchen is a smart and attractive woman; however, the only way she could get a better life is to seduce a rich man, single or married, healthy or dying. Again, the theme of female submission to male dominance is emphasized.

Kaplan argues that women like Flaemmchen did not only exist in literature or on screen. Since working girls at that time could hardly pursue independent intellectual and artistic lives, they were forced to use sexual appeals to win the affection of suitable but married men, playing roles as mistresses. Working-class women lacked the education to win men for more than their sexual attractions, which is exactly what Flaemmchen did in Grand Hotel [32]. Flaemmen's cavalier attitude toward relationships and sex led King to characterize her as "one of the many women in 1920s literature who on the surface represented emancipation, but actually were still portrayed as objects to be used by men or as ready willingly to submit to male domination in traditional relationships [33]."

According to Haralovich, in the 1930s, many Hollywood films positioned female characters in the narration within the fragile contours in which the morality of womanhood struggled with economic pressures. Products of the studio system, with stars and production values, these films also called upon recognition of the economic conditions of women. Their gendered and class identities were shown through the films [34].

American womanhood is highlighted in most films. We feel her need to be the heart and hearth of her home. There are films that made their ways to stand out by endowing women unique characteristics other than womanhood virtues. For example, in Jezebel (1938), Julie Marsden is a rebellious young girl. She was playing a game against men: "Girls don't have to simper around in white just because they're not married." Unfortunately, she lost the game. Julie is a spoiled girl who challenges social authorities but still ends up sacrificing herself to male dominance. Another impressive female image on screen can be found in Gone with the Wind (1939). The powerful and manipulative Scarlet O'Hara is no exception. Like other American women on screen, even though she can stand up to Yankees and carpetbaggers on her own, she is vulnerable before a polished, handsome man Rhett Butler. And her final realization is the value to cherish the love she had from her husband and family.

Besides the above, a lot of other well-known female film characters in 1930s are self-explanatory: the wealthy lady Ellie Andrews in It Happened One Night (1934), the desperate wife Helen Faraday in Blonde Venus (1932), and the vulnerable actress Ann Darrow in King Kong (1933). The generalizations are found in the portrayal of women in golden age Hollywood. Their roles have changed since the silent era, which was filled with female victims, women imperiled by the passivity and innocence enshrined by the cult of true womanhood [35]. Women on screen in 1930s often have part-time jobs such as dancer at night club, rather than staying at home as housewives. They have independent thinking but still need men's support for a better living status. They began to show their light of wit in this period but not too excessively to threaten men's dominance. In these changes are found traces in women's working status in film industry, the psychology of the "male gaze," and evidence of social as well as economic impacts on the studio system in 1930s.

\section{CONCLUSION}

In summary, female characters on screen in 1930s were portrayed in certain ways because with faded power of women filmmakers in the industry, the psychological needs of spectators, especially male spectators were addressed, while controls on motion pictures set a boundary for it. When Grand Hotel was released in April 1932, it quickly became a huge hit for MGM. With a budget of \$750,000, it enjoyed a box office of $\$ 2,250,000$. The female characters in the film were a portrayal of women in the golden age, which reflects the social reality and considerations of filmmakers. Conversely, the women on screen had an impact on women in the real world. The fascination with the movies revealed itself as a socializing force. Hollywood's ability to glamorize fashions persuaded women to think of themselves as certain types. According to Margaret Thorp, no fashion magazine was able to compete with Hollywood movies in shaping fashions and trends [36]. Likewise, women on screen set paradigms for women in the real world to imitate and gradually be more feminized toward what male gaze desires. Compared to the era after second-wave feminism, a lot of the plots in 1930s and 1940s films indicate that the issues filmmakers deemed important to women in that time period primarily involved romance and domesticity [37]. Themes such as career and female friendship did not take the primary 
focus but were developing gradually.

\section{ACKNOWLEDGMENT}

The author thanks Dr. Thomas G. Schatz from Department of Radio-TV-Film, the College of Communication, the University of Texas at Austin for his useful comments which have greatly improved the manuscript.

\section{REFERENCES}

[1] N. Nichols, "Program Notes," Texas Cinema, vol. 18, pp. 70-74, 1980

[2] L. J. King, "Menschen im Hotel/Grand Hotel: Seventy years of a popular culture classic," Journal of American \& Comparative Cultures, vol. 23 , pp. 17- 23,2000

[3] L. J. King, "Grand Hotel: the sexual politics of a popular culture classic," Women in German Yearbook, vol. 15, pp. 185-200, 1999.

[4] M. M. Lauzen, "Where are the film directors (who happen to be women)?" Quarterly Review of Film and Video, vol. 29, pp. 310-319, 2012.

[5] T. Slater, "Transcending Boundaries: lois weber and the discourse over women's roles in the teens and twenties," Quarterly Review of Film \& Video, vol. 18, pp. 266, July 2001.

[6] N. Cott, The Bond of Womanhood: Woman's Sphere in New English, 1780-1835, New Haven: Yale University Press, 1977, pp. 139-148.

[7] D. R. Casella, "Feminism and the female author: the not so silent career of the woman scenarist in Hollywood-1896-1930," Quarterly Review of Film and Video, vol. 23, pp. 217-235, Sep. 2006.

[8] A. Slide, The Memoirs of Alice Guy Blach'e, Trans. Roberta and Simone Blach'e, Meuchen, NJ: Scarecrow Press, 1986, pp. 9-10.

[9] J. Macpherson, "The market for scenarios," Picturegoer, vol. 2, pp. 40, Dec. 1921.

[10] P. Gilligan, "Lenore coffee: easy smiler, easy weeper," in Backstory: Interviews with Screenwriters of Hollywood's Golden Age, ed. 143 London, U.K.: University of California Press, 1986.

[11] A. Slide, The Memoirs of Alice Guy Blach'e, Trans. Roberta and Simone Blach'e, Meuchen, NJ: Scarecrow Press, 1986, pp. 73.

[12] M. M. Lauzen, "Where are the film directors (who happen to be women)?" Quarterly Review of Film and Video, vol. 29, pp. 310-319, 2012.

[13] L. Seger, When Women Call the Shots, New York: Henry Holt and Company, 1996, pp. 14.

[14] S. E. Glassberg, "Opening the curtain on playwright gender: an integrated economic analysis of discrimination in American theatre,' M. A. thesis, Princeton Univ., Princeton, NJ, 2009.

[15] S. E. Glassberg, "Opening the curtain on playwright gender: an integrated economic analysis of discrimination in American theatre," M. A. thesis, Princeton Univ., Princeton, NJ, 2009.

[16] A. Martin and V. M. Clark, What Women Wrote: Scenarios 1912-1929, Frederick, MD: University Publications of America, Cinema History Microfilm Series, 1987, ch. 5-6.

[17] L. J. King, "The image of fame: Vicki Baum in Weimar Germany," The German Quarterly, vol. 58, pp. 375-393, 1985.

[18] V. Baum, Es war alles ganz anders. Erinnerungen, Berlin: Ullstein, 1962. English: I Know What I'm Worth, London: M. Joseph, 1964.

[19] L. J. King, "Menschen im Hotel/Grand Hotel: Seventy Years of a Popular Culture Classic," Journal of American \& Comparative Cultures, vol. 23, pp. 18, 2000.
[20] S. Higashi, Virgins, Vamps, and Flappers: The American Silent Movie Heroine, Montreal: Eden Press Women's Publications, Inc, 1978, pp. $88-89$.

[21] N. Friday, Men in Love, New York: Dell Publishing, 1980.

[22] C. L. Strauss, The Elementary Structures of Kinship, London: Eyre \& Spottiswoode, 1969

[23] L. Mulvey, "Visual pleasure and narrative cinema," Screen, vol. 16, pp. 6-18, 1975.

[24] M. Stokes and R. Maltby, Hollywood Spectatorship: Changing Perceptions of Cinema Audiences, London: British Film Institute, 2001, pp. 79-90.

[25] N. Brown, "A New Movie-Going Public: 1930s Hollywood and the emergence of the "family' film," Historical Journal of Film, vol. 33, pp. 1-23, 2013.

[26] L. Mulvey, "Visual pleasure and narrative cinema," Screen, vol. 16, pp. 6-18, 1975.

[27] L. Mulvey, "On duel in the sun: afterthoughts on 'visual pleasure 91 and narrative cinema'," Framework, vol. 15, pp. 12, 1981.

[28] D. N. Rodowick, "The difficulty of difference," Wide Angle, vol. 5, pp. 4-15, 1982.

[29] T. Balio, Grand Design: Hollywood as a Modern Business Enterprise 1930-1939, History of the American Cinema, New York: Charles Scribner's Sons, 1993, pp. 61-62.

[30] W. Hays, "The cinema of tomorrow," Ladies Home Journal, pp. 6, 51, 53, July 1930.

[31] V. Baum, Menschen im Hotel. Ein Kolportageroman mit Hintergründen, Berlin: Ullstein, 1929, pp. 80-81.

[32] E. A. Kaplan, Women and Film, 1983, New York: Taylor \& Francis, 2001, pp. 38

[33] L. J. King, Best-Sellers by Design: Vicki Baum and the House of Ullstein, Detroit: Wayne State UP, 1988, pp. 185-200.

[34] M. B. Haralovich, "The proletarian woman's film of the 1930s: contending with censorship and entertainment," Screen, vol. 31, pp. 172-187, 1990.

[35] L. Fishbein, "The fallen woman as victim in early American film: soma versus psyche," Film \& History, vol. 17, pp. 50-61, Sep. 1987.

[36] M. F. Thorp, America at the Movies, New Haven, Conn: Yale University Press, 1939, pp. 117.

[37] K. Hollinger, Feminist Film Studies, New York: Taylor and Francis, 2012, pp. 36.

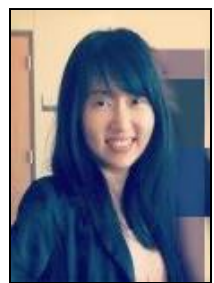

Dan Li was born in China. In 2007, Li earned Bachelor of Science in Finance at Beijing Foreign Studies University, Beijing, China. Li is now working on her Master of Arts in Advertising at the University of Texas at Austin, Austin, Texas, U.S. (expect graduation in 2014). She worked at Group M and Mindshare China as a Search Engine Marketing Manager for two and a half years before getting enrolled into graduate school. She has served world-wide famous brands including Nestle, BP, LG, Caterpillar and Cisco. Now, she works as a Graduate Assistant for the Department of Advertising and Public Relations at the University of Texas at Austin. Her research interests are digital media, new technologies, and online marketing. Ms. Li was a committee member of Excellence in Graduate Research Award, and currently a member in the Center for Research on Electronic Commerce, the University of Texas at Austin, Austin, Texas, U.S. 